\title{
ZNACZENIE PERSONALIZACJI KLIENTÓW W ZWIĘKSZANIU PRZEWAGI KONKURENCYJNEJ NA RYNKU PRZEDSIĘBIORSTW PRODUKCYJNYCH
}

\author{
Kamila Charciarek ${ }^{1}$ \\ Politechnika Częstochowska \\ Wydział Zarządzania
}

\begin{abstract}
Streszczenie: W niniejszym opracowaniu poruszono tematykę dotyczącą szeroko pojętej reorganizacji zarządzania współcześnie funkcjonujących przedsiębiorstw produkcyjnych. Wprowadzanie zmian $\mathrm{w}$ dotychczasowej działalności firm jest uzależnione od aktualnych uwarunkowań społeczno-gospodarczych, wynikających z postępującej świadomości klientów, między innymi w aspekcie użytkowania wysokiej jakości produktów, a także nowych możliwości ich zakupu i dystrybucji. Decyzje podejmowane w tym odniesieniu przez osoby zarządzające organizacjami stanowią o zwiększaniu ilości zasobów niematerialnych (dane i informacje), a tym samym realizacji zaplanowanych przedsięwzięć inwestycyjnych. W konsekwencji możemy mieć do czynienia z podażą dóbr, na które w określonym momencie występuje popyt. Celem opracowania jest zaprezentowanie roli klientów i zasadności procesów ich personalizacji $\mathrm{w}$ aspekcie sukcesywnego rozwoju przedsiębiorstw produkcyjnych poprzez zwiększanie przewagi konkurencyjnej na rynku. Ponadto na podstawie weryfikacji wyników, które pozyskano w ramach przeprowadzonych badań ankietowych w grupie losowo wybranych respondentów, dokonano oceny świadomości konsumentów na temat wykorzystywanych przez firmy sposobów nawiązywania z nimi relacji. W opracowaniu podjęto także próbę określenia poziomu zaawansowania omawianych procesów i wykorzystania w tym celu nowoczesnych rozwiązań $\mathrm{ICT}^{2} \mathrm{w}$ różnych sektorach gospodarczych polskich organizacji.
\end{abstract}

Słowa kluczowe: konkurencyjność przedsiębiorstw, personalizacja klientów, reorganizacja zarządzania podmiotami gospodarczymi, technologie informacyjno komunikacyjne (ICT)

DOI: $10.17512 /$ znpcz.2020.2.02

\section{Wprowadzenie}

Tempo zmian i uwarunkowań społeczno-gospodarczych stanowią o inwestycjach przedsiębiorstw oraz ich sukcesywnym rozwoju. Finansowanie nowych przedsięwzięć obejmuje przede wszystkim modernizację zaplecza technologicznego (zakup wysoko zaawansowanych maszyn i urządzeń produkcyjnych), informatycznego (narzędzia informacyjno-komunikacyjne i analityczne), a także wprowadzanie zmian $\mathrm{w}$ dotychczasowej kulturze zarządzania, między innymi w ujęciu procesowym ${ }^{3}$.

\footnotetext{
${ }^{1}$ Kamila Charciarek, mgr inż., kamilaa.francik@gmail.com, ORCID: 0000-0002-2656-239X

${ }^{2}$ ICT - (ang. Information and Communication Technologies) tcchnologic informacyjno-komunikacyjnc.

${ }^{3}$ Zarządzanie procesowe przedsiębiorstwami produkcyjnymi - A. Bitkowska definiuje niniejszy termin jako działania realizowane przez osoby zarządzające podmiotami gospodarczymi w ramach identyfikacji i fragmentaryzacji na poszczególne operacje składowe zachodzących w ich obrębie procesów.
} 
Przedsiębiorstwa, których nadrzędnym celem jest realizacja oczekiwań klientów, są skłonne do przeznaczania większej ilości środków finansowych na doskonalenie funkcjonowania obszarów odpowiedzialnych za weryfikację ich preferencji, co decyduje również o ukształtowaniu dynamiki i tempa procesów produkcyjnych wyrobów. Ma to na celu wyodrębnienie ewentualnych nieprawidłowości i ich eliminację przed rozpoczęciem dystrybucji produktów do klientów, jak również przeciwdziałanie wystąpieniu niniejszych czynników w przyszłości. Całokształt zmian w odniesieniu do sposobów zarządzania przedsiębiorstwami może przyczynić się do ugruntowania ich pozycji rynkowej na poziomie wyższym od firm konkurencyjnych (King 2016, s. 23; Pudło, Francik 2017, s. 27-38; Włodarczyk 2017, s. 117).

Niezależnie od profilu prowadzonej działalności podmiotów gospodarczych kluczowym elementem zaplanowanych projektów inwestycyjnych jest analiza zapotrzebowań popytowych oraz określenie predyspozycji przedsiębiorstw w tym odniesieniu (Grego-Planer, Liczmańska, Petrykowska 2013, s. 257). Działania takie stanowią szansę wytworzenia produktów mniej szablonowych, które w większym stopniu są dostosowane do oczekiwań konsumentów. Ponadto reorganizacja zarządzania podmiotami gospodarczymi powinna opierać się na przeświadczeniu pracowników i kadry zarządzającej o jej słuszności i pełnym wykorzystaniu dostępnych możliwości technologicznych i kapitału intelektualnego.

W niniejszym opracowaniu postawiono następującą hipotezę główną: Zastosowanie zaawansowanych technologii informacyjno-komunikacyjnych usprawnia realizację procesów personalizacji klientów w przedsiębiorstwach produkcyjnych, decydując o zwiększaniu ich przewagi konkurencyjnej na rynku. W celu weryfikacji hipotezy głównej wyodrębniono następujące hipotezy pomocnicze:

1. Wykorzystanie zaawansowanych technologii informacyjno-komunikacyjnych może znacząco wspierać procesy zarządzania przedsiębiorstwami produkcyjnymi i realizację przedsięwzięć inwestycyjnych poprzez pozyskiwanie większej ilości zasobów niematerialnych (dane i informacje) z ich otoczenia zewnętrznego i wewnętrznego.

2. Wysoko zaawansowane technologie informacyjno-komunikacyjne umożliwiają wykorzystanie rozwiązań $\mathrm{w}$ zakresie zarządzania procesowego przedsiębiorstwami produkcyjnymi, co stanowi o ustabilizowaniu relacji popytu i podaży dóbr, preferowanych w określonym czasie na rynku przez ich nabywców.

Należy także podkreślić, że opracowanie stanowić będzie zbiór informacji uzyskanych w ramach przeglądu literatury przedmiotu z uwzględnieniem najlepszych praktyk oraz wyników przeprowadzonych badań empirycznych. W ramach realizacji określonych celów oraz weryfikacji przedstawionych hipotez wykorzystane zostaną następujące metody i narzędzia badawcze:

Istotnym elementem omawianych zmian w sposobie funkcjonowania firm są także analiza, monitorowanie i kontrola procesów wytwórczych, a tym samym optymalizacja ich przebiegu. Według A. Bitkowskiej wdrożenie koncepcji procesowego zarządzania przedsiębiorstwami produkcyjnymi może w znaczącym stopniu przyczynić się do poprawy efektywności jednostki, wyprodukowania wyrobów o zwiększonych parametrach jakościowych i wydłużenia okresu ich użytkowania (Bitkowska 2009, s. 10-11). 
- W części teoretycznej - przegląd dostępnych źródeł literatury polskiej i zagranicznej, dotyczącej wpływu i znaczenia procesów personalizacji klientów na funkcjonowanie przedsiębiorstw produkcyjnych.

- W części empirycznej - przeprowadzenie badań ankietowych w grupie losowo wybranych respondentów oraz graficzna i statystyczna interpretacja uzyskanych wyników. Ponadto część empiryczna niniejszego opracowania będzie skoncentrowana na określeniu poziomu świadomości konsumentów w zakresie wykorzystywanych sposobów nawiązywania z nimi relacji w różnych sektorach gospodarczych przedsiębiorstw produkcyjnych za pośrednictwem nowoczesnych rozwiązań ICT.

\section{Rola personalizacji klientów w rozwoju przedsiębiorstw}

Postępujące zjawisko konkurencji rynkowej ${ }^{4}$ stanowi o umieszczeniu w centrum zainteresowania klienta, który z punktu widzenia decydentów firm jest determinantą ich sukcesywnego rozwoju. W związku z tym zwiększanie zasobów wiedzy na temat jego predyspozycji i oczekiwań jest głównym celem współcześnie funkcjonujących organizacji (Orzelska 2010, s. 229; Buchnowska 2006, s. 13-14).

M.E. Porter i M.R. Kramer w opracowaniu Creating Shared Value. How to Reinvent Capitalism and Unleash a Wave of Innovaion and Growth zwracają uwage na kluczową rolę klienta we współtworzeniu wartości dodanej przedsiębiorstw. Autorzy w swoich rozważaniach wskazują również, że czynnikiem ograniczającym rozwój firm jest ich dążenie do osiągnięcia jedynie korzyści ekonomicznych. Dlatego też M.E. Porter i M.R. Kramer wskazują, że opracowana i sukcesywnie realizowana strategia funkcjonowania organizacji powinna uwzględniać zastosowanie metod i narzędzi $\mathrm{w}$ procesie adaptacji do zmieniających się $\mathrm{w}$ radykalnym tempie czynników społecznych i ekologicznych (Porter, Kramer 2011). W tym odniesieniu warto zaprezen-tować także stanowisko B. Dobiegały-Korony. Autorka zaprezentowała pogląd, który stanowi, że osiągnięcie celów przedsiębiorstwa na poziomie wyższym od konkurencyjnych podmiotów gospodarczych wymaga uwzględnienia wagi i roli klienta w zaprojektowanym systemie produkcyjnym (Dobiegała-Korona 2012, s. 64-65).

Funkcjonowanie przedsiębiorstw na podstawie tradycyjnych modeli zarządzania odnosiło się do eliminacji trendów rynkowych oraz preferencji klientów (realizacja procesów wewnątrz przedsiębiorstwa). Co więcej, opracowana na tej podstawie strategia rozwoju była skoncentrowana na sprzedaży wytworzonej wartości dodanej poprzez wykorzystanie dostępnych koncepcji marketingowych. Dlatego też postępująca świadomość konsumentów wymusza na decydentach organizacji dostarczenie na rynek jedynie tych korzyści, za które są oni skłonni zapłacić (Stańczyk-Hugiet 2012, s. 78; Chomiak-Orsa 2013, s. 162).

\footnotetext{
${ }^{4}$ Zjawisko konkurencyjności przedsiębiorstw - oznacza zdolność organizacji do określenia nowych kierunków rozwoju oraz pozyskiwania i przetwarzania w tym celu kluczowych zasobów materialnych i niematerialnych, a także zastosowania nowoczesnych metod zarządzania i nawiązywania relacji z klientami. Konkurencyjność przedsiębiorstw stanowi o zwiększaniu zysków przedsiębiorstw ze sprzedaży wyprodukowanych wyrobów oraz o procesach decyzyjnych w aspekcie finansowania nowych przedsięwzięć, skoncentrowanych na osiągnięciu przewagi konkurencyjnej na rynku (Stankiewicz 2000, s. 79; Walczak 2010; Beyer 2012, s. 241-245).
} 


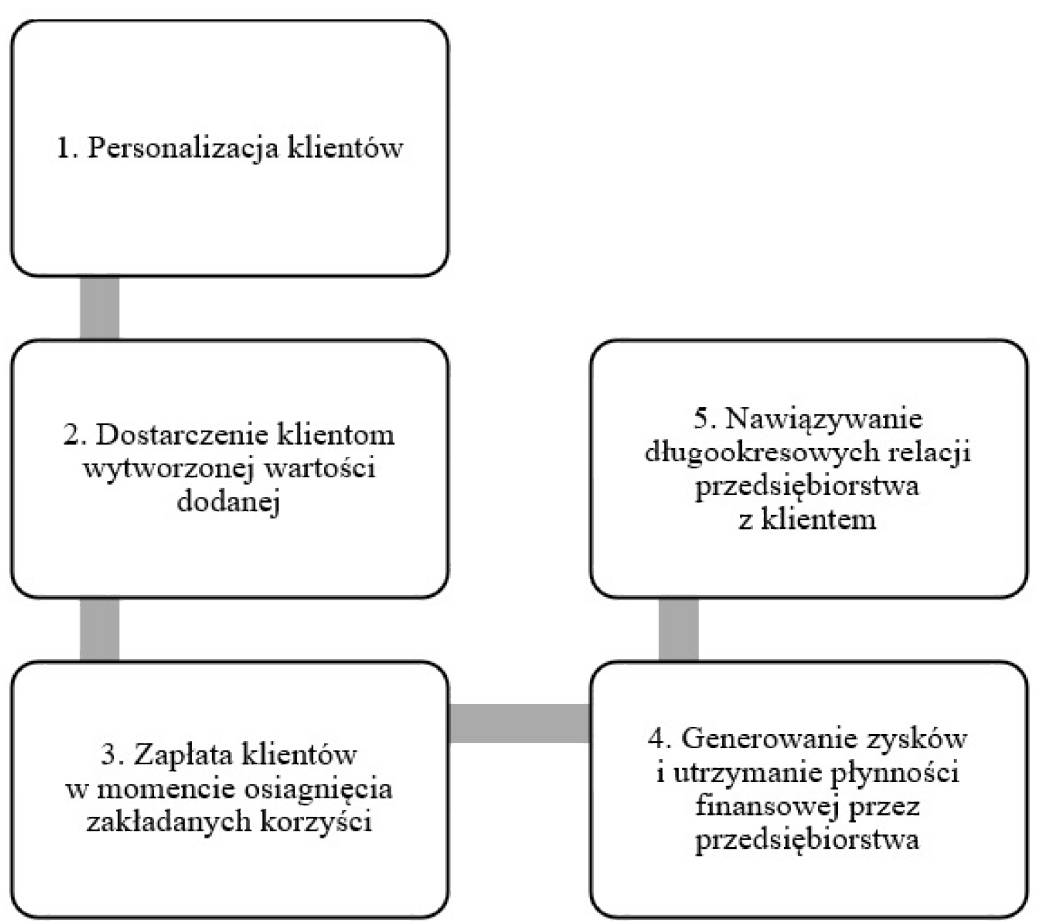

\section{Rysunek 1. Czynniki decydujące o realizacji oczekiwań klientów}

Źródło: Opracowanie własne na podstawie (Żak 2012, s. 735-736)

Ocena zaprezentowanych na Rysunku 1 czynników decydujących o realizacji oczekiwań klientów wykazała, że podejmowane przez nich decyzje w aspekcie zakupu określonych dóbr powinny być poprzedzone utworzeniem przez przedsiębiorstwa baz danych na temat wartości dodanej, którą aktualnie są oni zainteresowani. Z kolei wystąpienie jakichkolwiek nieprawidłowości w trakcie użytkowania wyrobów, jak również brak zainteresowania $\mathrm{w}$ tym odniesieniu ze strony producentów stanowi o weryfikacji oferty konkurencyjnych firm i prawdopodobieństwie zakończenia dotychczasowej współpracy. Warto podkreślić, że uwarunkowania społeczno-gospodarcze stwarzają nowe możliwości realizacji określonych celów strategicznych (Andruszkiewicz 2015, s. 180-181). W związku z tym przedsiębiorstwo powinno być definiowane terminem systemu, w którym zaplanowanie przebiegu poszczególnych procesów decyduje o wykorzystaniu szans i okazji występujących w ich otoczeniu (Charciarek, Pudło 2019, s. 167-177). Niemniej jednak całokształt działań wymaga od kierownictwa firm umiejętnego wykorzystywania ich mocnych stron, przy jednoczesnej eliminacji występujących zagrożeń - optymalizacja poziomu ryzyka biznesowego ${ }^{5}$ (Moczulska, Stankiewicz 2016, s. 121; Francik,

\footnotetext{
${ }^{5}$ Ryzyko biznesowe - zaprezentowane w literaturze przedmiotu definicje są zróżnicowane ze względu na dowolność ich interpretacji. Niemniej jednak należy podkreślić, że ryzyko biznesowe odnosi się do wszystkich podejmowanych przez przedsiębiorstwa działań, które mogą przyczynić się do uzyskania zarówno pozytywnych, jak i negatywnych skutków ich funkcjonowania na rynku. K. Francik,
} 
Pudło 2016b, s. 23-24). Elementem sukcesywnego rozwoju przedsiębiorstw są zatem działania skoncentrowane na pozyskiwaniu, przetwarzaniu oraz przechowywaniu danych i informacji na temat aktualnych oczekiwań klientów (procesy personalizacji i analizy rynkowej). Dlatego też zwiększa się liczba podmiotów gospo-darczych, która decyduje o finansowaniu szeroko pojętej działalności innowacyjnej, takiej jak implementacja zaawansowanych technologii informacyjnych. Reorganizacja zarządzania poszczególnymi obszarami przedsiębiorstw w znaczącym stopniu wpływa na skrócenie czasu wykonania zaplanowanych operacji oraz eliminacji możliwych nieprawidłowości przebiegu procesów wytwórczych. Pośród wyodrębnionych narzędzi ICT można wskazać zróżnicowane narzędzia informatyczne i analityczne, takie jak (Smart Industry Polska 2018, s. 35):

- chmura obliczeniowa (ang. Cloud Computing),

- eksploracja danych (ang. Data Mining),

- Big Data,

- Internet Rzeczy (ang. Internet of Things),

- Internet Wrzechrzeczy (ang. Internet of Everythings),

- technologie mobilne.

Zagwarantowanie dostępu do sieci Internet pozwala na przekształcenie realizowanych procesów w czasie rzeczywistym, które zostało poprzedzone analizą aktualnych preferencji klientów. Ponadto możemy mieć do czynienia z optymalizacją poziomu ryzyka popełnienia błędów podczas przebiegu poszczególnych procesów wytwórczych lub ich eliminacją przed dostarczeniem wyrobów gotowych do ich przyszłych użytkowników (Markiewicz 2014, s. 153-154; Charciarek, Pudło 2019, s. 167-177). W związku z tym należy podkreślić, że opracowana strategia rozwoju firm produkcyjnych powinna eskalować dążenie osób nimi zarządzających do sukcesywnego zwiększania efektywności i produktywności całej jednostki, a tym samym dostarczenia klientom produktów najwyżej jakości na każdym etapie ich użytkowania (Piwoni-Krzeszowska 2014, s. 67).

Zaspokojenie potrzeb konsumentów wymaga podjęcia przez przedsiębiorstwa działań w zakresie ustabilizowania relacji podaży i popytu określonych dóbr. Wymaga to również nawiązania z klientami długookresowej współpracy, której konsekwencje będą jednoznaczne $\mathrm{z}$ ich przywiązaniem do określonej marki i z ponownym zakupem wyprodukowanych przez nią wyrobów. Poprawa parametrów sprzedaży wynika także ze zwiększenia liczby stałych klientów i ciągłego zapewniania o lojalności i predyspozycjach firm w aspekcie przekształcania procesów produkcyjnych na podstawie pozyskanych informacji o ich indywidualnych upodobaniach (Francik, Pudło 2016a, s. 107-118).

M. Charciarek i M. Pudło w swoich rozważaniach na temat omawianego terminu wyodrębnili jego pejoratywne określenia, takie jak: brak satysfakcji, niepewność oraz nieprzewidywalność, które w perspektywie dłuższego okresu czasu mogą stanowić o zagrożeniu płynności finansowej jednostki (decyzje o realizacji określonych przedsięwzięć inwestycyjnych). Ryzyko biznesowe może także wpłynąć na zwiększenie przychodów ze sprzedaży wyprodukowanych wyrobów i umocnienie pozycji konkurencyjnej firm poprzez pozyskanie nowych klientów lub nawiązanie długookresowych relacji z dotychczasowymi poprzez realizację ich oczekiwań (Francik, Charciarek, Pudło 2015, s. 204-307). 


\section{Wyniki badań ankietowych}

Dążenie przedsiębiorstw produkcyjnych do doskonalenia realizowanych procesów oraz wdrażanie w tym odniesieniu nowoczesnych metod zarządzania jest obciążone dużym poziomem ryzyka biznesowego. Dlatego też w tych sektorach gospodarczych firm zgromadzenie i umiejętne wykorzystanie zasobów niematerialnych (wiedza na temat uwarunkowań zachodzących $\mathrm{w}$ otoczeniu zewnętrznym i wewnętrznym, umiejętności pracowników) może przyczynić się do poprawy wyników finansowych oraz ugruntowania pozycji konkurencyjnej na rynku (Francik, Pudło 2016 c, s. 41). W tym celu osoby zarządzające przedsiębiorstwami decydują o uwzględnieniu w przyjętej strategii rozwoju procesów pozyskiwania, przekształcania, gromadzenia i transferu informacji.

Dla potrzeb niniejszego opracowania przeprowadzono badanie ankietowe, którego celem było określenie poziomu świadomości klientów na temat realizowanych za ich pośrednictwem przez polskie przedsiębiorstwa produkcyjne procesów analizy rynkowej (personalizacja klientów). Ponadto elementem niniejszych badań była weryfikacja stopnia, w jakim firmy są skłonne do wprowadzania zmian w opracowanej strategii rynkowej w celu zwiększenia znaczenia personalizacji klientów i wyprodukowania wyrobów odpowiadających ich oczekiwaniom.

Badania zostały przeprowadzone w czerwcu 2020 roku i wzięło w nich udział 86 osób, których przedział wiekowy był zróżnicowany. W grupie badawczej znajdowało się 68 kobiet i 18 mężczyzn. Wiek ponad połowy ankietowanych zawierał się w przedziale 19-29 lat, co stanowi 82,6\% ogólnej liczby respondentów, którzy zdecydowali o udziale w badaniu. Kwestionariusz ankietowy został wykonany w formie elektronicznej na stronie Formularze Google i udostępniony na portalu społecznościowym Facebook oraz stronie internetowej TwojePajęczno.pl. Z uwagi na losowy dobór grupy badawczej wykształcenie osób ankietowanych było zróżnicowane. Największy odsetek respondentów stanowiły osoby, które ukończyły studia wyższe, uzyskując stopień: licencjata $(12,8 \%)$, inżyniera $(9,3 \%)$, magistra $(33,7 \%)$ oraz ponadmagisterski $(7 \%)$. Oprócz tego ankietowani posiadali także wykształcenie: zasadnicze zawodowe (2,3\%) i średnie (34,9\%).

Jedną z dostępnych form personalizacji klientów oraz przedstawienia propozycji oferty i cen wyrobów (na podstawie weryfikacji zgromadzonych danych i informacji) jest tak zwana karta stałego klienta, czy też karta rabatowa. Dlatego też pierwsze postawione pytanie $\mathrm{w}$ utworzonym kwestionariuszu ankietowym było następujące: Czy otrzymał/a Pan/Pani kartę rabatową lub stałego klienta w jakimkolwiek sklepie stacjonarnym lub internetowym? (Rysunek 2).

Analiza pozyskanych wyników badań wykazała, że przeważająca liczba osób, które zdecydowały o wypełnieniu niniejszego formularza ankietowego, udzieliła twierdzącej odpowiedzi na zaprezentowane pytanie. Oznacza to, że przedsiębiorstwa produkcyjne wykorzystują zwiększenie dostępu społeczeństwa do sieci Internet i za pośrednictwem powszechnych narzędzi ICT decydują o analizie uwarunkowań zachodzących w ich otoczeniu zewnętrznym. Zaproponowanie konsumentom możliwości utworzenia karty rabatowej lub stałego klienta wymaga wskazania aktualnego numeru telefonu lub adresu poczty e-mail, co stanowi nową formę nawiązywania 
z nimi kontaktu. Jednocześnie w momencie jej wykorzystania przez klientów podczas zakupu określonych dóbr producenci dokonują klasyfikacji grup wyrobów oraz zaplanowania na tej podstawie ich procesów wytwórczych. Przeważająca liczba respondentów wskazała także, że dokonanie płatności w wybranym sklepie stacjonarnym lub internetowym jest poprzedzone poinformowaniem sprzedawcy o posiadaniu niniejszego dokumentu. Rozkład odpowiedzi na postawione pytanie: Czy w momencie zakupu określonych produktów wykorzystuje Pan/Pani kartę rabatową lub kartę stałego klienta? kształtował się następująco:

- tak $-90,7 \%$ ankietowanych,

- nie $-9,3 \%$ ankietowanych,

- nie wiem - ankietowani nie dokonali wyboru tego wariantu odpowiedzi.

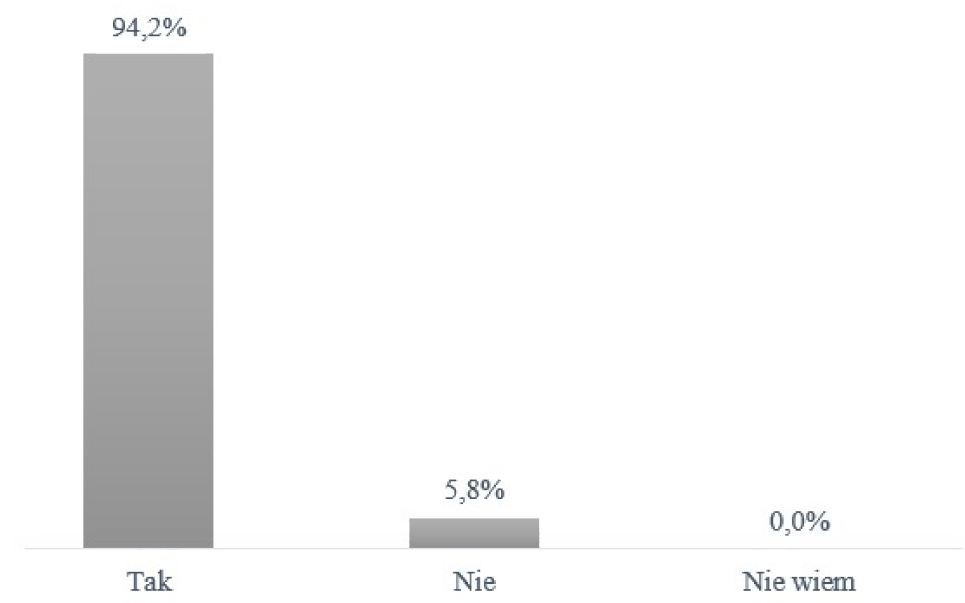

Rysunek 2. Rozkład odpowiedzi na pytanie: Czy otrzymal/a Pan/Pani kartę rabatową lub stalego klienta $\mathrm{w}$ jakimkolwiek sklepie stacjonarnym lub internetowym?

Źródło: Opracowanie własne

Z punktu widzenia konsumentów niniejsze uwarunkowania mogą wynikać z możliwych do osiągnięcia korzyści, m.in. takich jak niższa cena produktów, których użytkowaniem są oni zainteresowani w określonym miejscu i czasie (Rysunek 3).

W przypadku znaczącej liczby osób ankietowanych udzielona odpowiedź na postawione pytanie była twierdząca, co potwierdza, że podmioty gospodarcze wykorzystują możliwość weryfikacji oczekiwań i preferencji klientów, ale także powszechne formy komunikacji (sieć Internet) do nawiązania z nimi bezpośredniego kontaktu. Ponadto dążą one do przekazania konsumentom informacji zwrotnej o uwzględnieniu ich potrzeb w aktualnej ofercie sprzedaży. Na tej podstawie można wysnuć wniosek, że zmienia się sposób definiowania klienta przez osoby zarządzające współcześnie funkcjonującymi w sektorze produkcji firmami. Niniejsze uwarunkowania podkreślają także interdyscyplinarny charakter technologii informacyjno-komunikacyjnych oraz perspektywy oszczędności w tym odniesieniu środków 
finansowych poprzez możliwość ich zastosowania w różnych obszarach przedsiębiorstw. Jednocześnie zaobserwowano, że przedstawienie przez firmy perspektyw wykorzystania karty stałego klienta lub rabatowej dla osób nimi zarządzających jest nowym narzędziem zaplanowanej i realizowanej kampanii marketingowej (przesłanie oferty sprzedaży na wskazany adres e-mail). Dlatego też podjęto decyzję o sformułowaniu następującego pytania: Czy po uzyskaniu karty rabatowej lub karty stałego klienta otrzymuje Pan/Pani wiadomości (SMS, e-mail) na temat oferty produktów, odpowiadających Pana/Pani oczekiwaniom? Przeważająca liczba respondentów wskazała, że pozyskują informacje na temat wyprodukowanego asortymentu przez poszczególne podmioty gospodarcze w inny sposób, co potwierdza następujący rozkład udzielonych odpowiedzi:

- nie $-33,7 \%$ ankietowanych,

- nie wiem $-17,4 \%$ ankietowanych.

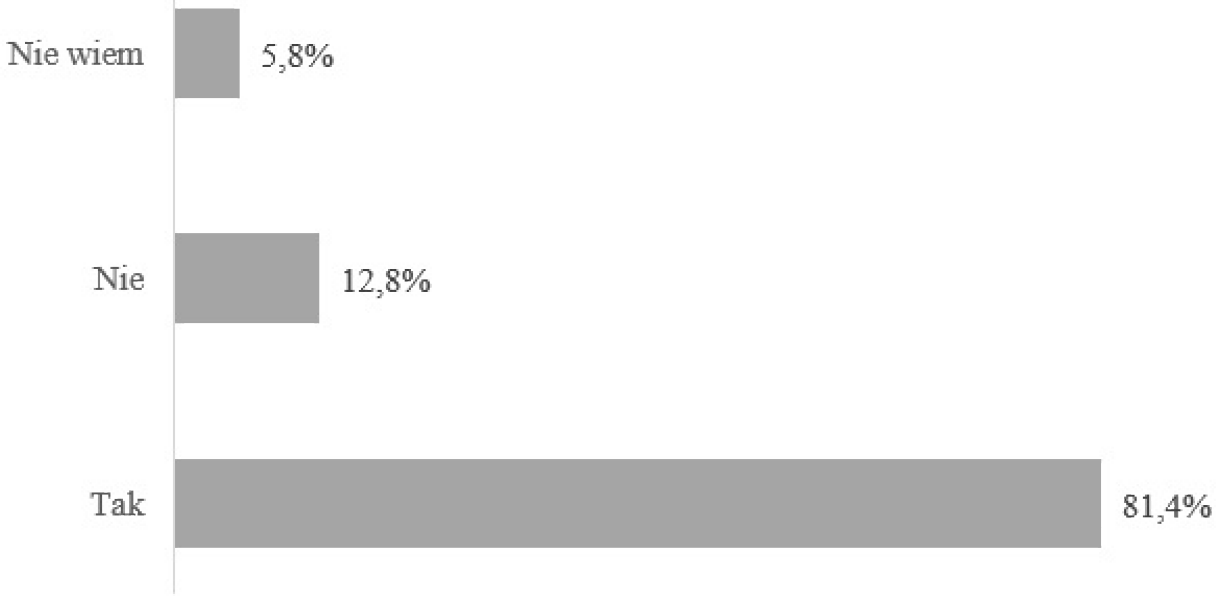

Rysunek 3. Rozkład odpowiedzi na pytanie: Czy po uzyskaniu karty rabatowej lub karty stałego klienta otrzymuje Pan/Pani wiadomości (SMS, e-mail) na temat aktualnych promocji?

Źródło: Opracowanie własne

Suma udzielonych odpowiedzi może oznaczać, że te obszary przedsiębiorstw wymagają reorganizacji zarządzania i zwiększenia w tym odniesieniu możliwości przekazywania klientom informacji zwrotnej o dążeniu do dostosowania aktualnej oferty sprzedaży do ich oczekiwań. Wówczas możemy mieć do czynienia ze zwiększeniem poziomu zaufania konsumentów do określonej marki (poczucie intensyfikacji podejmowanych działań w zakresie podtrzymania nawiązanych relacji). Pozostałe osoby udzieliły odpowiedzi pozytywnej, co stanowi 48,8\% ogólnej liczby respondentów.

Elementem niniejszego badania była również ocena wpływu wprowadzonych zmian w dotychczasowym sposobie funkcjonowania firm na możliwość zwiększenia sprzedaży wyprodukowanych dóbr, a tym samym osiąganych wyników finansowych (Rysunek 4). 


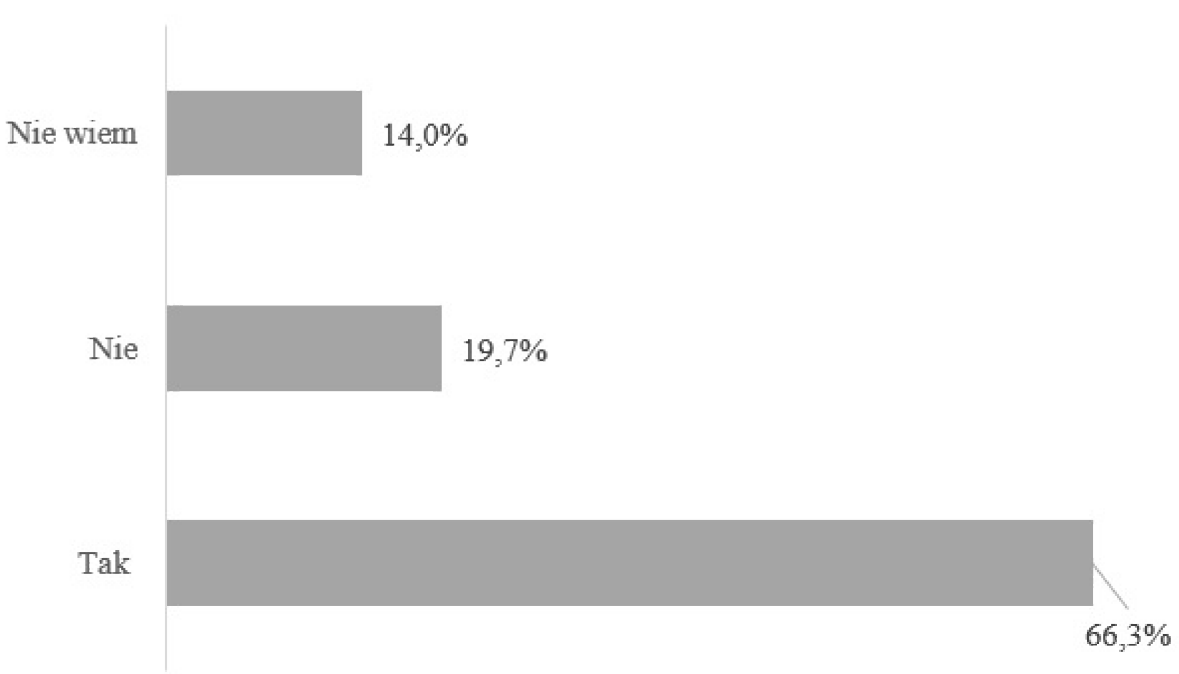

Rysunek 4. Rozkład odpowiedzi na pytanie: Czy aktualne promocje i rabaty zachęcają Pana/Panią do zakupu określonych produktów?

Źródło: Opracowanie własne

Zaprezentowany na Rysunku 4 rozkład odpowiedzi na pytanie wskazuje, że podjęcie decyzji przez klientów o zakupie wybranych produktów jest uzależnione od poziomu ich ceny. Dlatego też utworzenie kart stałego klienta lub rabatowych i poinformowanie uczestników rynku o wprowadzeniu promocji lub wyprzedaży wyrobów może zwiększyć prawdopodobieństwo ich zakupu. Ponadto drugim istotnym czynnikiem może okazać się przeświadczenie klientów o realizacji procesów produkcyjnych na ich życzenie. Za pośrednictwem omawianych form personalizacji klientów podmioty gospodarcze nieustannie monitorują zachodzące relacje popytu i podaży dóbr i w konsekwencji oferują ich niższą cenę w obawie o podobne działania firm konkurencyjnych. Jednocześnie za pośrednictwem tej formy promocji, marketingu lub personalizacji klientów zarządzający organizacjami są skłonni do obniżenia ceny produktów, które $\mathrm{w}$ określonym czasie nie spotkały się z aprobatą konsumentów. Niemniej jednak należy podkreślić, że niniejsze działania są obciążone dużym poziomem ryzyka biznesowego i stanowią próbę funkcjonowania na nowych rynkach.

Istotą działalności przedsiębiorstw jest sprzedaż wyprodukowanych wyrobów. W tym odniesieniu można zaobserwować, że poszczególne jednostki gospodarcze decydują o określeniu oczekiwań klientów poprzez wykorzystanie narzędzi, takich jak: Google Maps, fora dyskusyjne czy dane statystyczne (wielopoziomowa personalizacja i profilowanie klientów w czasie rzeczywistym) - Rysunek 5. Na rysunku zaprezentowano rozkład odpowiedzi udzielonych na pytanie: Czy po dokonaniu zakupów w wybranym sklepie stacjonarnym lub internetowym otrzymuje Pan/Pani wiadomości (SMS, e-mail) z prośbą oceny jakości obsługi sprzedaży oraz zakupio- 
nych produktów? Analiza pozyskanych w tym zakresie wyników badań ankietowych wykazała, że przedsiębiorstwa wykorzystują nowoczesne i popularne narzędzia ICT w odniesieniu do weryfikacji poziomu jakości wyrobów lub oceny przeprowadzonej usługi ich sprzedaży.

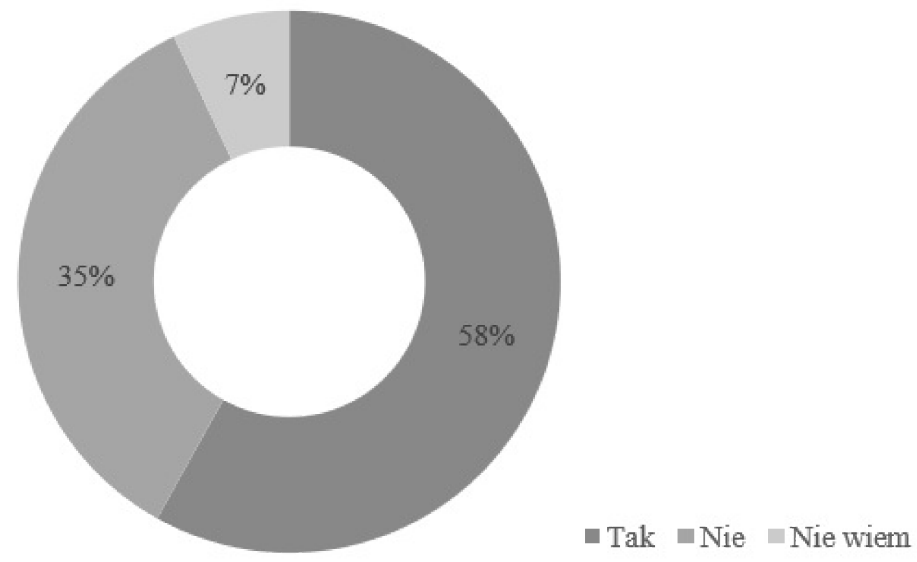

Rysunek 5. Rozkład odpowiedzi na pytanie: Czy po dokonaniu zakupów w wybranym sklepie stacjonarnym lub internetowym otrzymuje Pan/Pani wiadomość (SMS, e-mail) z prośbą o ocenę jakości obsługi sprzedaży oraz zakupionych produktów?

Źródło: Opracowanie własne

Wielokrotnie mamy do czynienia z różnymi kategoriami klientów, którzy dokonują oceny walorów użytkowych produktów na podstawie sposobów ich obsługi w punkcie sprzedaży (stacjonarnym lub online). Wykorzystanie możliwości dotarcia do większej liczby osób za pośrednictwem sieci Internet stanowi o ciągłym transferze i wymianie informacji, a tym samym doskonaleniu i modyfikacji poszczególnych procesów na podstawie spostrzeżeń konsumentów. Odpowiedzi udzielone przez respondentów wskazują, że elementem realizowanej strategii przedsiębiorstw produkcyjnych jest zarządzanie nimi w ujęciu procesowym. Uwzględnia ona przede wszystkim ciągłe analizowanie oraz monitorowanie postaw i aktywności klientów, począwszy od określenia ich oczekiwań, wyprodukowania poszczególnych grup produktów, a skończywszy na procesach ich dystrybucji i sprzedaży w utworzonych punktach sprzedaży. Celem szeroko pojętych zmian w tych obszarach funkcjonowania przedsiębiorstw jest przekonanie klienta o jego roli i znaczeniu w sukcesywnym rozwoju jednostki oraz budowaniu przynależności i zaufania do konkretnej marki.

\section{Podsumowanie}

Przedmiotem rozważań zaprezentowanych w niniejszym opracowaniu była problematyka zgodna z tytułem artykułu: Znaczenie personalizacji klientów w zwiększaniu przewagi konkurencyjnej na rynku przedsiębiorstw produkcyjnych. W odniesieniu do tematu opracowania wyznaczono jego cel główny, który odnosił się do 
zaprezentowania roli klientów i zasadności procesów ich personalizacji w aspekcie sukcesywnego rozwoju firm produkcyjnych, funkcjonujących w różnych sektorach gospodarczych. Na podstawie sformułowanego celu głównego dokonano weryfikacji określonej na wstępie opracowania hipotezy głównej, która stanowi, że zastosowanie zaawansowanych technologii informacyjno-komunikacyjnych usprawnia realizację procesów personalizacji klientów w przedsiębiorstwach produkcyjnych, decydując o zwiększaniu ich przewagi konkurencyjnej na rynku. Analiza zdefiniowanych założeń była możliwa przede wszystkim poprzez zgromadzenie danych i informacji w ramach przeprowadzonych badań empirycznych w grupie losowo wybranych respondentów. W tym celu wykorzystano narzędzie badawcze w postaci elektronicznego formularza ankietowego, który opracowano na stronie internetowej Formularze Google i udostępniono za pośrednictwem ogólnodostępnych form masowego przekazu. Z kolei ocena dwóch hipotez pomocniczych była wynikiem przeglądu dostępnej literatury polskiej i zagranicznej, który ograniczono do określenia wpływu i znaczenia procesów personalizacji klientów na funkcjonowanie przedsiębiorstw produkcyjnych w różnych sektorach gospodarczych.

W sektorze przedsiębiorstw produkcyjnych można zaobserwować skłonność i dążenie do inwestycji środków finansowych w aspekcie wdrażania nowoczesnych form nawiązywania relacji oraz kontaktu z klientami i przyszłymi użytkownikami wyprodukowanych dóbr. W tym celu firmy na etapie sprzedaży produktów wykorzystują karty stałego klienta lub karty rabatowe. Pośród korzyści zaprezentowanych projektów inwestycyjnych można wskazać m.in.: redukcję lub zmniejszenie kosztów przedsiębiorstwa czy też zwiększenie poziomu adaptacji do aktualnych trendów rynkowych. Analiza wyników pozyskanych w ramach przeprowadzonych badań ankietowych wykazała, że podmioty gospodarcze decydują o realizacji projektów innowacyjnych, które są skoncentrowane na zakupie i implementacji zaawansowanych rozwiązań technologicznych, informatycznych i komunikacyjnych, na co wskazują udzielone przez respondentów odpowiedzi na postawione pytania. Osoby, które zdecydowały o udziale w niniejszym badaniu, wskazywały, że firmy specjalizujące się w produkcji wyrobów, które są obszarem ich zainteresowań, wielokrotnie nawiązują z nimi kontakt za pośrednictwem nowoczesnych form komunikacji, takich jak przesłanie wiadomości e-mail lub SMS. Ponadto wyodrębnione podmioty gospodarcze według respondentów są skłonne zaoferować atrakcyjne ceny wyrobów, co stanowi o podjęciu przez nich decyzji o nawiązaniu transakcji kupna-sprzedaży. Zastosowanie tego rodzaju narzędzi w znaczącym stopniu może przyczynić się do usprawnienia zarządzania organizacją $\mathrm{w}$ ujęciu procesowym poprzez możliwość lokalizacji i zaprojektowania procesów, realizowanych w poszczególnych komórkach organizacyjnych. Całokształt działań ma na celu ich modyfikację i nadzorowanie, a w konsekwencji zapewnienie parametrów na podstawie informacji pozyskiwanych w czasie rzeczywistym. Niniejsze uwarunkowania gospodarcze stanowią o potwierdzeniu wyodrębnionych hipotez pomocniczych:

- Wykorzystanie zaawansowanych technologii informacyjno-komunikacyjnych może znacząco wspierać procesy zarządzania przedsiębiorstwami produkcyjnymi i realizację przedsięwzięć inwestycyjnych poprzez pozyskiwanie większej 
ilości zasobów niematerialnych (dane i informacje) z ich otoczenia zewnętrznego i wewnętrznego.

- Wysoko zaawansowane technologie informacyjno-komunikacyjne umożliwiają wykorzystanie rozwiązań w zakresie zarządzania procesowego przedsiębiorstwami produkcyjnymi, co stanowi o ustabilizowaniu relacji popytu i podaży dóbr, preferowanych w określonym czasie na rynku przez ich nabywców.

Realizacja badań ankietowych w wyodrębnionej próbie badawczej oraz przegląd dostępnej literatury w zakresie omawianej tematyki potwierdziły również, że dążenie przedsiębiorstw produkcyjnych do realizacji procesów personalizacji klientów jest podyktowane zwiększeniem prawdopodobieństwa nawiązania z nimi relacji w dłuższym okresie czasu, a tym samym ugruntowaniem pozycji rynkowej na poziomie wyższym od firm konkurencyjnych. Oznacza to konieczność lokacji nakładów kapitałowych na finalizację projektów, których głównym celem jest określanie zapotrzebowań rynku, a także podaż wyrobów przez poszczególne grupy przedsiębiorstw. Wobec zaprezentowanych uwarunkowań gospodarczych wiedza stanowi kluczowy zasób organizacji, którego umiejętne wykorzystanie za pośrednictwem zaaplikowanych, nowoczesnych technologii informacyjno-komunikacyjnych stanowi o reorganizacji zarządzania podmiotami gospodarczymi.

$\mathrm{Na}$ podstawie analizy pozyskanych wyników w ramach przeprowadzonych badań ankietowych oraz przeglądu literatury przedmiotu stwierdza się, że determinantą rozwoju współczesnych przedsiębiorstw jest realizacja procesów personalizacji klientów. Istotnym elementem w tym odniesieniu jest zastosowanie zaawansowanych technologii informacyjno-komunikacyjnych oraz gromadzenie na tej podstawie większej ilości zasobów wiedzy w poszczególnych obszarach firm. Całokształt działań ma także bezpośredni wpływ na organizację stanowisk pracy, przebieg procesów wytwarzania i dostarczania klientom produktów wysokiej jakości, a w konsekwencji realizację ich potrzeb i oczekiwań. Dlatego też można wysnuć wniosek, że zaprezentowane uwarunkowania stanowią uzasadnienie dla postawionej hipotezy głównej: zastosowanie zaawansowanych technologii informacyjno-komunikacyjnych usprawnia realizację procesów personalizacji klientów w przedsiębiorstwach produkcyjnych, decydując o zwiększaniu ich przewagi konkurencyjnej na rynku.

\section{Literatura}

1. Andruszkiewicz K. (2015), Marketingowe kierunki rozwoju polskich przedsiębiorstw, „Zeszyty Naukowe Uniwersytetu Szczecińskiego. Problemy Zarządzania, Finansów i Marketingu", nr 41, t. 2.

2. Beyer K. (2012), Kapitat intelektualny jako podstawa przewagi konkurencyjnej przedsiębiorstw, „Zeszyty Naukowe Uniwersytetu Szczecińskiego. Studia i Prace Wydziału Nauk Ekonomicznych i Zarządzania", nr 25.

3. Bitkowska A. (2009), Zarzadzanie procesami biznesowymi w przedsiębiorstwie, Wizja PRESS \& IT, Warszawa.

4. Buchnowska D. (2006), CRM strategia i technologia, Wydawnictwo Uniwersytetu Gdańskiego, Gdańsk.

5. Charciarek K., Pudło M. (2019), Zaawansowane technologie informacyjne wspomagające nawiązywanie kontaktów z klientem, „Zarządzanie i Finanse”, R. 17. cz. 1, nr 1. 
6. Chomiak-Orsa I. (2013), Zarzadzanie kapitałem relacyjnym w procesie wirtualizacji organizacji. Podejście modelowe, Wydawnictwo Uniwersytetu Ekonomicznego we Wrocławiu, Wrocław.

7. Dobiegała-Korona B. (2012), Nowa rola marketingu w budowaniu wartości przedsiębiorstwa, „Kwartalnik Nauk o Przedsiębiorstwie”, nr 2.

8. Francik K., Charciarek M., Pudło M. (2015), Ryzyko i innowacje w działalności przedsiębiorstwa, [w:] Kiełtyka L., Jędrzejczyk W. (red.), Wykorzystanie potencjału współczesnych technologii informacyjnych $w$ zarzadzaniu organizacjami, Wydawnictwo Politechniki Częstochowskiej, Częstochowa.

9. Francik K., Pudło M. (2016a), Systemy wspomagajace relacje z klientami w aspekcie zarzadzania ryzykiem w przedsiębiorstwie, [w:] Kościelniak H., Brendzel-Skowera K. (red.), Wyzwania i perspektywy przedsiębiorczej organizacji, t. 1, Wydawnictwo Wydziału Zarządzania Politechniki Częstochowskiej, Częstochowa.

10. Francik K., Pudło M. (2016b), Systemy wspomagania decyzji w aspekcie zarzadzania ryzykiem w przedsiębiorstwie, „Zeszyty Naukowe Politechniki Częstochowskiej. Zarządzanie”, nr 22.

11. Francik K., Pudło M. (2016c), Znaczenie wiedzy w zarządzaniu ryzykiem w przedsiębiorstwie, [w:] Smoląg K., Wrzalik A. (red.), Rozwój i doskonalenie funkcjonowania organizacji. Teoretyczne i praktyczne aspekty zarządzania współczesną organizacją, Wydawnictwo Wydziału Zarządzania Politechniki Częstochowskiej, Częstochowa.

12. Grego-Planer D., Liczmańska K., Petrykowska J. (2013), Korzyści wynikajace z budowania dlugotrwatych relacji z klientami $w$ firmach usługowych, „Polityki Europejskie, Finanse i Marketing", nr 10(59).

13. King J. (2016), W stronę klienta, „Computerworld”, marzec.

14. Markiewicz J. (2014), Nowa rola klienta w procesie tworzenia wartości, „Acta Universitatis Nicolai Copernici. Zarządzanie", t. 41, nr 2.

15. Moczulska M., Stankiewicz J. (2016), Interakcje społeczne sprzyjajace zaangażowaniu pracowników $w$ organizacji-założenia $w$ świetle teorii organizacji $i$ zarządzania, „Nauki o Zarządzaniu", nr 2 (27).

16. Orzelska P. (2010), System CRM podstawa sukcesu zarządzania relacjami z klientami, [w:] Skrzypek E. (red.), Mat. Konf. Ogólnopolskiej Konferencji Naukowej: Klient jako wyznacznik sukcesu organizacji, Lublin.

17. Piwoni-Krzeszowska E. (2014), Zarządzanie wartością relacji przedsiębiorstwa z rynkowymi interesariuszami - aspekt procesu tworzenia wartości, „Nauki o Zarządzaniu”, nr 1(18).

18. Porter P.H., Kramer M.R. (2011), Creating Shared Value. How to Reinvent Capitalism and Unleash a Wave of Innovation and Growth, „Harvard Business Review”, January-February.

19. Pudło M., Francik K. (2017), Cyfryzacja przedsiębiorstw sektora MSP w dażeniu do organizacji horyzontalnej, „Ekonomika i Organizacja Przedsiębiorstwa”, nr 10(813).

20. Smart Industry Polska 2018. Innowacyjność w sektorze mikro oraz matych i średnich przedsiębiorstw produkcyjnych $w$ Polsce. Raport z badań (2018), Ministerstwo Przedsiębiorczości i Technologii / Siemens, Warszawa.

21. Stankiewicz M.J. (2000), Istota i sposoby oceny konkurencyjności przedsiębiorstwa, „Gospodarka Narodowa", nr 7-8.

22. Stańczyk-Hugiet E. (2012), Niematerialne zasoby sieci międzyorganizacyjnych, [w:] Niemczyk J., Stańczyk-Hugiet E., Jasiński B. (red.), Sieci międzyorganizacyjne. Współczesne wyzwania dla teorii i praktyki zarzadzania, C.H. Beck, Warszawa.

23. Walczak W. (2010), Analiza czynników wpływajacych na konkurencyjność przedsiębiorstw, „E-mentor", nr 5(37).

24. Włodarczyk R. (2017), Działalność innowacyjna polskich przedsiębiorstw, „Zeszyty Naukowe Politechniki Częstochowskiej. Zarządzanie", nr 25, t. 2.

25. Żak K. (2012), Zaufanie i zaangażowanie jako determinanty budowania wartości klienta oraz wartości przedsiębiorstwa, „Zeszyty Naukowe Uniwersytetu Szczecińskiego. Finanse, Rynki Finansowe, Ubezpieczenia", nr 55. 


\title{
THE IMPORTANCE OF CUSTOMER PERSONALIZATION IN INCREASING COMPETITIVE ADVANTAGE ON THE MANUFACTURING ENTERPRISE MARKET
}

\begin{abstract}
This study deals with the subject of the broadly understood reorganization of management of modern manufacturing enterprises. Introducing changes in the current operations of companies depends on the current socio-economic conditions resulting from the increasing awareness of customers, including the aspect of using high-quality products, as well as new opportunities for their purchase and distribution. The decisions taken in this regard by organizations' management constitute an increase in the amount of intangible resources (data and information), and thus the implementation of planned investment projects. Consequently, there may be a supply of goods which are in demand at a certain moment. The purpose of the study is to present the role of clients and the legitimacy of their personalization processes in the aspect of the successive development of manufacturing enterprises by increasing their competitive advantage on the market. In addition, based on the verification of the results, which were obtained as part of surveys carried out in a group of randomly selected respondents, an assessment of consumer awareness of the methods used by companies to establish relationships with them was made. The study also attempts to determine the level of advancement of the processes in question and use modern ICT solutions in various economic sectors of Polish organizations for this purpose.
\end{abstract}

Keywords: competitiveness of enterprises, customer personalization, information and communication technologies (ICT), reorganization of business entity management 